\title{
Antiurolithiatic Activity of the Leaf Extracts of Maerua Angolensis
}

\author{
Abimelek Solomon, Adiam Andemariam, Feven Tseghehannes, Hermon Aron, Meron Tesfagaber, Zebib \\ Andemeskel, Dawit Tesfay and Atul Kaushik* \\ Department of Medical Sciences, Orotta College of Medicine and Health Sciences, Eritrea
}

*Corresponding author: Atul Kaushik, Department of Medical Sciences, Unit of Pharmacy, Orotta College of Medicine and Health Sciences, 118, Asmara, Eritrea.

Received Date: October 16, 2019

Published Date: October 23, 2019

\begin{abstract}
A wide range of medicinal plants have been used conservatively for urolithiaisis due to their fewer side effects and because they contain copious phytochemicals that show advantageous effects in urolithiasis. Maerua angolensisis traditionally used in the treatment of urolithiasis in Eritrea. It is a small African tree growing west to Senegal, in Somalia, Ethiopia, and south to Natal. Maerua angolensis (keremo) was selected as there are no scientific reports available on the plant for anti-urolithiatic activity. In vitro anti-urolithiatic activity of the plant extracts was tested in terms of inhibition of calcium oxalate nucleation, aggregation and growth assays in the presence as well as absence of inhibitors. Three different concentrations $(10 \mathrm{mg} / \mathrm{ml}, 20 \mathrm{mg} / \mathrm{ml}$, and $30 \mathrm{mg} / \mathrm{ml})$ of the plant extracts were tested in each assay. Phytochemical screening revealed the presence of alkaloids, flavonoids, amino acids, tannins, phenols, saponins, resins, carbohydrates and proteins. Among all the extracts of $M$. angolensis, the highest percentage nucleation inhibition was obtained from water extract at a concentration of $30 \mathrm{mg} / \mathrm{ml}(95.5 \%)$. The aqueous, chloroform and ethanol extracts ( 10 and $30 \mathrm{mg} / \mathrm{ml})$ were found to possess significant anti-urolithiatic activity when compared to standard Cystone (10 and $30 \mathrm{mg} /$ $\mathrm{ml}$ ). In the aggregation assay, the highest percentage aggregation inhibition was obtained from chloroform extract at a concentration of $30 \mathrm{mg} / \mathrm{ml}$ $(196.25 \%)$. The chloroform extracts $(10,20,30 \mathrm{mg} / \mathrm{ml})$ was found to have anti-urolithiatic activity with significant difference when compared with cystone (standard drug). As revealed in the comparison of the percentage growth inhibition by the three extracts of M. angolensis, the chloroform extract at the concentration of $30 \mathrm{mg} / \mathrm{ml}$ was found to be the most effective. The highest percentage dissolution of calcium oxalate of Maerua angolensis was found from ethanol extract at the concentration of $30 \mathrm{mg} / \mathrm{ml}(55.73 \%)$. The aqueous extract (10 and $20 \mathrm{mg} / \mathrm{ml})$ was statistically different when compared to Cystone standard (10 and $20 \mathrm{mg} / \mathrm{ml})$. The study concludes that the leaf extracts of Maerua anglensis have inhibitory effect on calcium oxalate for crystal nucleation, aggregation and crystal growth. It also showed great efficacy in the dissolution of calcium oxalate crystals. Thus these extracts may be valuable resources for treatment of urolithiasis.
\end{abstract}

Keywords: Urolithiasis; Maerua angolensis; Nucleation assay; Aggregation assay; Growth assay

Abbreviations: UV: Ultraviolet; MAA: Maerua Angolensis Aqueous; MAE: Maerua Aangolensis Ethanol; MAC: Maerua Angolensis Chloroform

\section{Introduction}

The term urolithiaisis (Greek- 'ouron' for urine, 'oros' for flow, and 'lithos' for stone) refers to the formation of solid concretions consisting of both protein and crystalline materials in the lumen of urinary tract attached to the uro-epithelium [1]. Urolithiasis is a major health problem that affects $12 \%$ of the global population [2]. It is more prevalent between the ages of 20 to 40 in both sexes, with a male to female ratio of 2:1 [3]. Urinary calculi may have various compositions which include: calcium oxalate (monohydrate or dihydrate), struvite (magnesium ammonium phosphate), uric acid, calcium phosphate, and cystine. There are other less common stones, including xanthine and drug-related stones as well. Globally, calcium oxalate is considered as the main constituent in the renal calculi and represents about $80 \%$ of all the cases [4,5]. A wide range of medicinal plants have been used in different countries and cultures as a prophylactic and curative agent for urolithiasis $[6,7,8]$. They have been used conventionally for urolithiaisis due to their cost effectiveness, fewer side effects and because they contain numerous phytochemicals that show beneficial effects in urolithiasis [9]. Maerua angolensis Figure 1 is traditionally used in the treatment of urolithiasis in Eritrea. It is a shrub or small tree, usually growing 5-6 m tall but with reports of some trees up to $10 \mathrm{~m}$ tall. The plant is often rather rambling, with spreading or drooping 
braches. The bole is rarely straight. It is a small African tree growing west to Senegal, in Somalia, Ethiopia, and south to Natal. It is used in the treatment of various diseases such as asthenia and anorexia, rheumatism, epilepsy, headache, pus-filled abscesses, hydrocoele, influenza, toothache in addition to its use as an analgesic [10]. By keeping all the points in mind the study has been designed and undertaken to evaluate the phytoconstituents and anti-urolithiatic potential of the leaf extracts of Maerua angolensis using in vitro methods. Maerua angolensis (keremo) was selected as there are no scientific reports available on the plant for anti-urolithiatic activity (Figure 1).
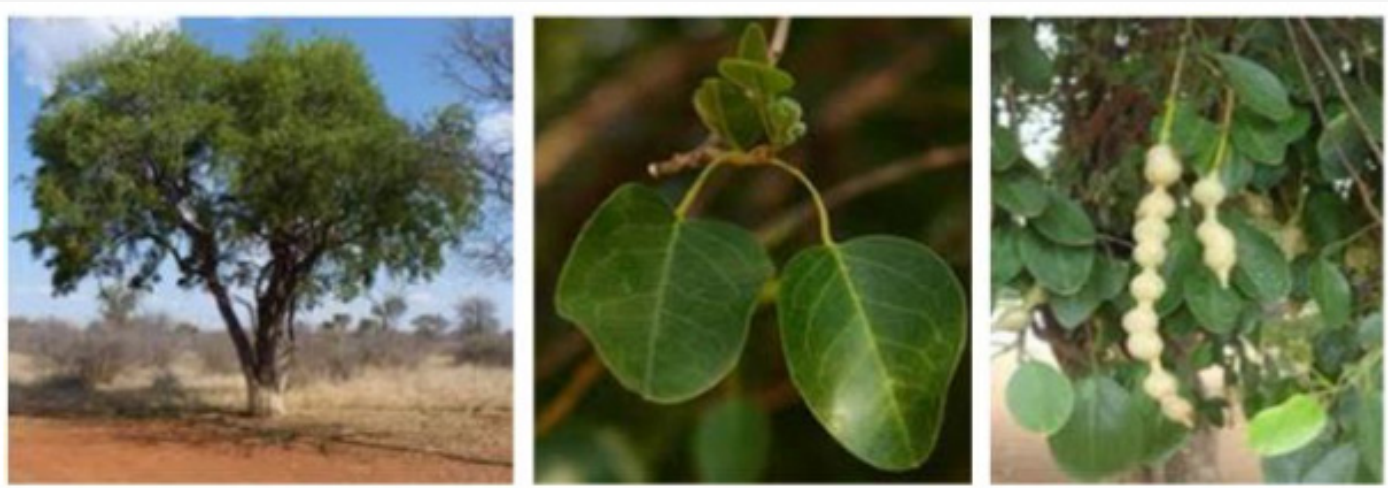

Figure 1: Maerua angolensis (keremo).

\section{Materials and Methods}

\section{Collection and processing of plant materials}

The plant was collected from Shiketi (Menguda) (Figure 1), southern region of Eritrea, from June, $22^{\text {nd }}-29^{\text {th }}, 2018$. The plant was authenticated by a botanist, Department of Botany, Eritrean Institute of Technology, Minefi, Eritrea. The leaves of Maerua angolensis (Keremo) were washed with tap water to eliminate any dust or other foreign particles. The plant leaves were then shade dried for two weeks and coarsely powdered. The powdered materials were passed through a $4 \mathrm{~mm}$ sieve and stored in clean containers until the time of use.

\section{Preparation of various extracts}

Cold extraction method was used to prepare various extracts from the leaves of Maerua angolensis using water, ethanol and chloroform. 150g of the leaf powder was weighed and transferred in to Erlenmeyer flasks. $1000 \mathrm{ml}$ of each solvent was added to each flask and the flasks were closed tightly. Each flask was kept in a Stuart Scientific shaker at 150 revolutions per minute (rpm) for three days. Content of the flasks were filtered through a single layer of muslin cloth, and then the final filtrate was collected by passing it through a Whattman grade 1 filter paper in a Buchner funnel under vacuum to obtain pure liquid extract. All extracts were then concentrated by using a rotary evaporator. The concentrated extracts obtained were left to dry at room temperature. All the extracts were kept till further use. All the prepared extracts were subjected to qualitative chemical tests to detect the presence of different classes of phytoconstituents namely alkaloids, flavonoids, steroid, glycoside, reducing sugar, proteins and amino acids, resins, quinones, tannins and saponins.

\section{Evaluation for anti-urolithiatic activity}

Turbidometric method: The in vitro anti-urolithiatic activity of the plant extracts was tested in terms of inhibition of calcium oxalate nucleation, aggregation and growth in the presence of inhibitors (standard drug and extracts) and absence of inhibitors. A UV/Visible spectrophotometer (Jasco V-630) was employed to measure the turbidity changes in each assay. Three different concentrations $(10 \mathrm{mg} / \mathrm{ml}, 20 \mathrm{mg} / \mathrm{ml}$, and $30 \mathrm{mg} / \mathrm{ml})$ of the plant extracts were tested in each assay.

- Nucleation assay: Solutions of calcium chloride and sodium oxalate were prepared at the final concentrations of 5 $\mathrm{mmol} / \mathrm{L}$ and $7.5 \mathrm{mmol} / \mathrm{L}$ respectively in a buffer containing Tris $0.05 \mathrm{~mol} / \mathrm{L}$ and $\mathrm{NaCl} 0.15 \mathrm{~mol} / \mathrm{L}$ at $\mathrm{pH}$ 6.5. $950 \mu \mathrm{L}$ of calcium chloride solution was mixed with $100 \mu \mathrm{L}$ of plant extract at different concentrations $(10 \mathrm{mg} / \mathrm{ml}, 20 \mathrm{mg} / \mathrm{ml}$ and $30 \mathrm{mg} / \mathrm{ml}$ ). Crystallization was started by adding 950 $\mu \mathrm{L}$ of sodium oxalate solution and the temperature was maintained at $37^{\circ} \mathrm{C}$. The optical density of the solution was monitored at $620 \mathrm{~nm}$. The rate of nucleation was estimated by comparing the induction time in the presence of the extract with that of control. Cystone tablets were used as standard solution (11). Percentage inhibition of nucleation was calculated using the following formula: \% Inhibition of nucleation $=[(\mathrm{C}-\mathrm{S}) / \mathrm{C}] \times 100$. Where, $\mathrm{C}$ is the turbidity without extract and $\mathrm{S}$ is the turbidity with extract.

- $\quad$ Aggregation assay: COM crystals were prepared by mixing calcium chloride and sodium oxalate at $50 \mathrm{mmol} / \mathrm{L}$. Both solutions were equilibrated to $60^{\circ} \mathrm{C}$ in a water bath for 1 $\mathrm{h}$ and then cooled to $37^{\circ} \mathrm{C}$ overnight. The crystals were harvested by centrifugation and then evaporated at $37^{\circ} \mathrm{C}$. The CaOx crystals were used at a final concentration of 0.8 $\mathrm{mg} / \mathrm{ml}$, buffered with Tris $0.05 \mathrm{~mol} / \mathrm{L}$ and $\mathrm{NaCl} 0.15 \mathrm{~mol} / \mathrm{L}$ at $\mathrm{pH}$ 6.5. The experiments were conducted in the absence and presence of the plant extract after stopping stirring. Cystone tablets were used as standard drug solution [11]. The percentage aggregation inhibition rate (Ir) was 
calculated by comparing the turbidity in the presence of the extract with that obtained in the control using following the following formula: Ir = (1-Turbiditysample/Turbidity control) $\times 100$. Where, Ir is the percentage aggregation inhibition rate.

- Growth assay: The percentage inhibition of calcium oxalate crystal growth was evaluated in presence and absence of plant extracts. $4 \mathrm{mM}$ calcium chloride and $4 \mathrm{mM}$ sodium oxalate of $1 \mathrm{ml}$ each were added to a $1.5 \mathrm{ml}$ of solution containing sodium chloride $(10 \mathrm{mM})$ buffered with Tris $(10 \mathrm{mM})$ at $\mathrm{pH} 7.2$. To this $30 \mu \mathrm{l}$ of calcium oxalate monohydrate crystal slurry $(1.5 \mathrm{mg} / \mathrm{ml}$ acetate buffer $)$ was added. Consumption of oxalate begins immediately after COM slurry addition and was monitored for 30 minutes for disappearance of absorbance at $214 \mathrm{~nm} .100 \mu \mathrm{l}$ of each plant extracts were separately added into the reaction mixture. The depletion of free oxalate ions will decrease if extract inhibits calcium oxalate crystal growth. Rate of reduction of free oxalate was calculated using the baseline value and the value with or without extract after 30 minutes of incubation [11]. The relative inhibitory activity was calculated by the following formula: \% relative inhibitory activity $=((\mathrm{C}-\mathrm{S}) / \mathrm{C})$ $\times 100$. Where, $\mathrm{C}$ is the rate of reduction of free oxalate without any extract and $S$ is the rate of reduction of free oxalate with drug extract.

\section{Titrimetric method}

This method was used to evaluate the activity of the plant extracts in dissolving the already formed stones in the kidneys. The steps involved in the process were as follows:

- Step 1: Preparation of experimental kidney stones (Calcium oxalate stones) by homogenous precipitation

$1.47 \mathrm{gm}$ of calcium chloride dihydrate was dissolved in $100 \mathrm{ml}$ distilled water and $1.34 \mathrm{gm}$ of sodium oxalate was dissolved in 100 $\mathrm{ml}$ of $2 \mathrm{~N} \mathrm{H} 2 \mathrm{SO} 4$. Both solutions were mixed equally in a beaker

\section{Results and Discussion}

\section{Results of Phytochemical screening}

Table 1: Results of Phytochemical screening.

\begin{tabular}{|c|c|c|c|c|c|c|c|c|c|c|}
\hline $\begin{array}{l}\text { Solvents } \\
\text { used for } \\
\text { extraction }\end{array}$ & Alkaloids & $\begin{array}{c}\text { Proteins } \\
\text { and amino } \\
\text { acids }\end{array}$ & Carbohydrates & Steroids & Tannins & Glycosides & Flavonoids & Saponins & Resins & Quinones \\
\hline Ethanol & + & + & - & - & + & + & + & + & + & + \\
\hline Water & + & + & + & - & + & + & + & + & + & - \\
\hline Chloroform & + & - & - & - & + & + & + & + & + & + \\
\hline
\end{tabular}

Phytochemical screening Table 1 revealed the presence of alkaloids, flavonoids, amino acids, tannins, phenols, saponins, resins, carbohydrates and proteins. Different activities observed in the plant extracts might be due to the presence of these phytochemicals. For example, Tannins and polyphenols inhibit $\mathrm{CaOx}$ crystal formation as well as dissolve the preformed $\mathrm{CaOx}$ to precipitate out calcium oxalate with stirring. The resulting precipitate was calcium oxalate which was freed from traces of sulfuric acid by treating with ammonia solution. Finally, it was washed with distilled water and dried at a temperature of $60{ }^{\circ} \mathrm{C}$ until all the water was evaporated [12].

\section{- Step 2: Preparation of the semi permeable membrane} from farm eggs

The semi-permeable membrane of eggs lies in between the outer calcified shell and the inner contents like albumin \& yolk. The preparation included the following steps: Apex of eggs was punctured by a glass rod in order to squeeze out the entire content. Empty eggs were washed thoroughly with distilled water and placed in a beaker consisting $2 \mathrm{M} \mathrm{HCl}$ for an overnight, which caused complete decalcification. Then, the semi-permeable membranes were washed with distilled water, placed in ammonia solution for neutralization of acid traces in the moistened condition for a while and was then rinsed with distilled water. Finally, the egg membranes were stored in $2 \%$ ammonia until used [13].

\section{- Step 3: Estimation of Calcium oxalate by Titrimetry}

Exactly $5 \mathrm{gm}$ of calcium oxalate and $10 \mathrm{mg}, 20 \mathrm{mg}$ and $30 \mathrm{mg}$ of each plant extract were packed together in the semi-permeable membrane of egg. These were allowed to suspend in a conical Erlenmeyer flask containing $100 \mathrm{ml}$ of $0.1 \mathrm{M}$ Tris buffer. All the conical flasks were placed in water bath at $37^{\circ} \mathrm{C}$ for an overnight. Then, the semi permeable membranes along with theinside contents were removed from the conical flasks. $2 \mathrm{ml}$ of $1 \mathrm{~N}$ sulfuric acid was added to the contents remaining in the flask and was titrated with $0.1356 \mathrm{M}$ of KMnO4 till a light pink color was obtained. Each first group containing only $5 \mathrm{mg}$ of calcium oxalate served as blank. The second group containing $5 \mathrm{mg}$ of calcium oxalate and along with the $10,20,30 \mathrm{mg} / \mathrm{ml}$ of standard formulation that is, Cystone served as a positive control. The $3^{\text {rd }}$ and $4^{\text {th }}$ groups contained $5 \mathrm{mg}$ of calcium oxalate and $1 \mathrm{ml}$ of aqueous and ethanolic extracts at a concentration of 10,20 and $30 \mathrm{mg} / \mathrm{ml}$. All the experiments were performed in duplicate. Finally, the amount of calcium oxalate dissolved was calculated using the mole concept. 
Anti-urolithiatic activities of the leaf extracts of Maerua angolensis

The aqueous, ethanol and chloroform extract of Maerua angolensis, inhibited crystal formation as well as promoted crystal dissolution in a dose dependent manner and were comparable to the activity of Cystone. From all the extracts, the highest percentage nucleation inhibition was obtained from water extract at a concentration of $30 \mathrm{mg} / \mathrm{ml}$ (95.5\%). The aqueous, chloroform and ethanol extracts (10 and $30 \mathrm{mg} / \mathrm{ml}$ ) were found to possess significant anti-urolithiatic activity when compared to standard Cystone (10 and $30 \mathrm{mg} / \mathrm{ml}$ ). These findings were consistent with the activity of the aqueous extract of Bauhinia variegate which was $94.2 \%$ at $1000 \mathrm{mcg} / \mathrm{ml}$, as demonstrated in the study by Vani Mamillapali et al, at the Vijaya Institute of Pharmaceutical Sciences for Women, in 2016. They also indicated that the plant was effective in inhibiting aggregation and growth using turbidity assays [15] (Table 2 \& Figure 2).

Table 2: Results of anti-urolithiatic activities of the leaf extracts of Maerua angolensis.

\begin{tabular}{|c|c|c|c|c|c|}
\hline Type of Extract & Concentration & $\begin{array}{l}\% \text { inhibition of } \\
\text { Nucleation }\end{array}$ & $\begin{array}{l}\% \text { inhibition of } \\
\text { Aggregation }\end{array}$ & $\begin{array}{l}\% \text { inhibition of } \\
\text { Growth }\end{array}$ & $\%$ dissolution \\
\hline \multirow{3}{*}{ Aqueous extract } & $10 \mathrm{mg} / \mathrm{ml}$ & 2.96 & 20.42 & 13.7 & 4.29 \\
\hline & $20 \mathrm{mg} / \mathrm{ml}$ & 20.7 & 40.63 & 67 & 12.86 \\
\hline & $30 \mathrm{mg} / \mathrm{ml}$ & 95.5 & 93.61 & 72.08 & 17.15 \\
\hline \multirow{3}{*}{ Ethanol extract } & $10 \mathrm{mg} / \mathrm{ml}$ & 9.05 & 11.25 & 23.8 & 21.44 \\
\hline & $20 \mathrm{mg} / \mathrm{ml}$ & 12.25 & 38.33 & 56.85 & 47.16 \\
\hline & $30 \mathrm{mg} / \mathrm{ml}$ & 22 & 53.54 & 95.94 & 55.73 \\
\hline \multirow{3}{*}{ Chloroform extract } & $10 \mathrm{mg} / \mathrm{ml}$ & 0.66 & 13.47 & 87.77 & - \\
\hline & $20 \mathrm{mg} / \mathrm{ml}$ & 2.67 & 93.95 & 114.3 & - \\
\hline & $30 \mathrm{mg} / \mathrm{ml}$ & 14.22 & 196.25 & 181.12 & - \\
\hline \multirow{3}{*}{ Cystone } & $10 \mathrm{mg} / \mathrm{ml}$ & 29.14 & 42.57 & 23.25 & 34.3 \\
\hline & $20 \mathrm{mg} / \mathrm{ml}$ & 32 & 50.8 & 44.16 & 49.3 \\
\hline & $30 \mathrm{mg} / \mathrm{ml}$ & 50.4 & 62.36 & 94.73 & 55.73 \\
\hline
\end{tabular}

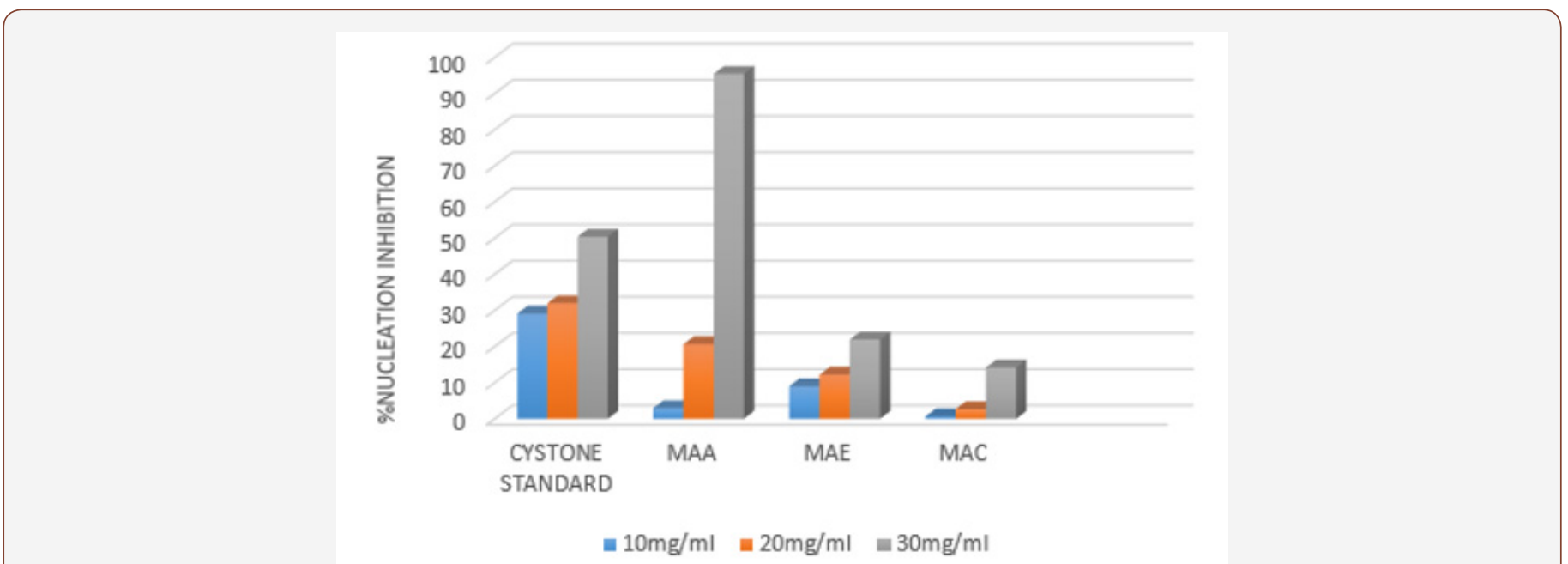

Figure 2: Comparison of the Percentage Nucleation Inhibition of Calcium Oxalate by Maerua angolensis with Cystone.

In the aggregation assay of different extracts of Maerua angolensis, the highest percentage aggregation inhibition was obtained from chloroform extract at a concentration of $30 \mathrm{mg} /$ $\mathrm{ml}(196.25 \%)$. The chloroform extracts $(10,20,30 \mathrm{mg} / \mathrm{ml})$ was found to have anti-urolithiatic activity with significant difference when compared with cystone standard (10, 20 and $30 \mathrm{mg} /$ $\mathrm{ml}$ ). (Figure 3) As revealed in the comparison of the percentage growth inhibition by the three extracts of Maerua angolensis, the chloroform extract at the concentration of $30 \mathrm{mg} / \mathrm{ml}$ was found to be the most effective. However, there was no significant difference in the anti-urolithiatic activity as compared with Cystone. (Figure 4) Pronounced anti-urolithiatic activity was found in in-vitro anti-urolithiatic model for calculating percentage dissolution of kidney stone when titration method was performed. The highest percentage dissolution of calcium oxalate of Maerua angolensis was found from ethanol extract at the concentration of $30 \mathrm{mg} / \mathrm{ml}$ (55.73\%). The aqueous extract ( 10 and $20 \mathrm{mg} / \mathrm{ml}$ ) was statistically different when compared to Cystone standard (10 and $20 \mathrm{mg} / \mathrm{ml}$ ). These results were comparable to the results of ethanolic extracts of Gossypiumherbaceum (87\%) in the study done by Niharika M. et al., in 2018 at the Vishnu institute of pharmaceutical education and research, India. In addition, they found that the aqueous extract of Gossypiumherbaceumwas also effective with a percentage dissolution of $64 \%$ [16]. An additional study done by Vennila et 
al., at DGGA College in India in 2015, revealed a high percentage of dissolution (72.72\%) by the aqueous extract of Meliadubia. The acetone extract, however, had the greatest activity at a percentage of $98 \%$ [17] (Figure 3,4 \&5).
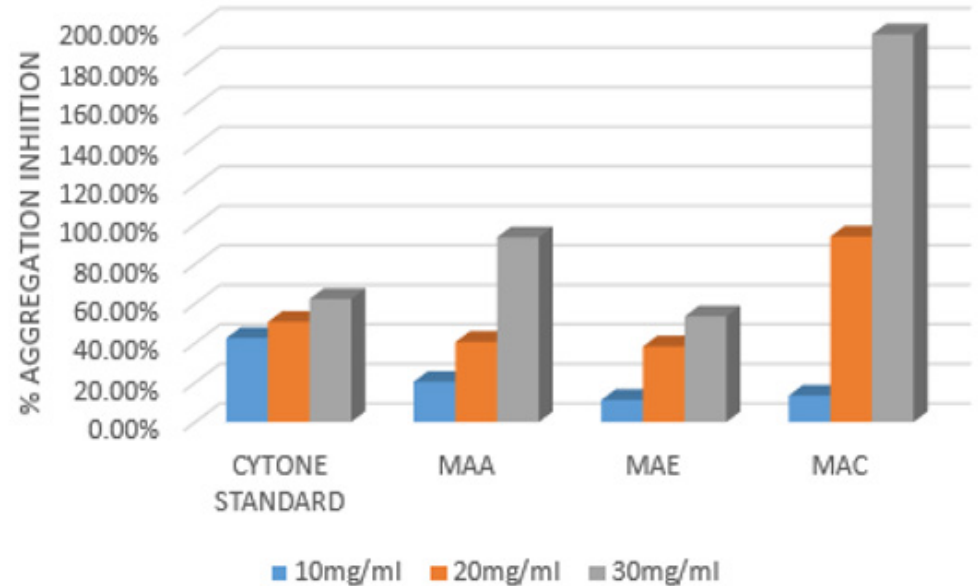

Figure 3: Comparison of the Percentage Aggregation Inhibition of Calcium Oxalate by Maerua angolensis with Cystone.

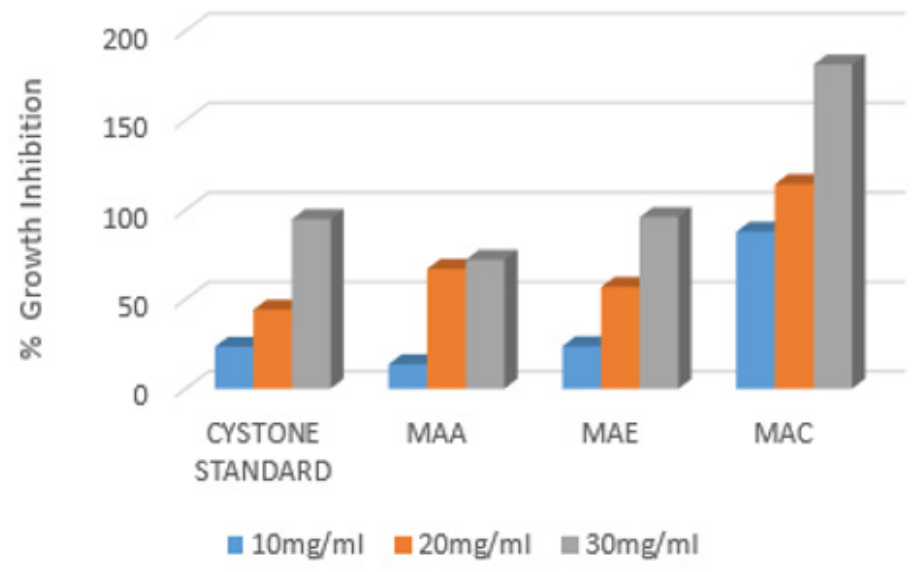

Figure 4: Comparison of the Percentage Growth Inhibition of Calcium Oxalate by Maerua angolensis with Cystone.

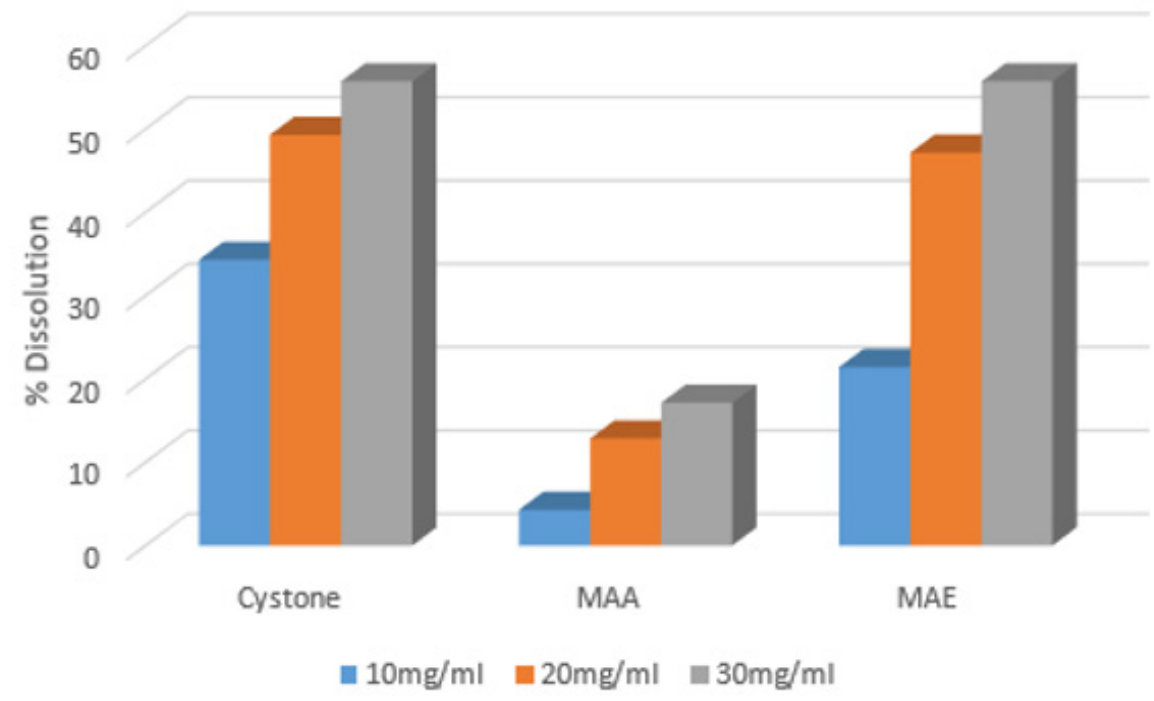

Figure 5: Comparison of the Percentage dissolution of Calcium Oxalate by Maerua angolensis with Cystone.. 


\section{Conclusion}

Findings of the present study clearly demonstrate antiurolithiatic potential of Maerua angolensis against calcium oxalate urolithiasis in vitro. The plant showed prominent inhibition of all the phases of calcium oxalate stone formation which include nucleation, aggregation and growth. It also showed great efficacy in the dissolution of calcium oxalate crystals. This plant is used in ethnomedical practice in the treatment of urinary problems and renal stones. The study has given a basic scientific evidence for the traditional uses of the plant in the prevention and treatment of urolithiasis. Therefore, this plant could be a potential source of new drug molecules with anti-urolithiatic activity.

\section{Acknowledgment}

None.

\section{Conflict of Interest}

No conflict of interest.

\section{References}

1. Chandra Shekhar Tailor, Anju Goyal (2015) Isolation of Phytoconstituents and in vitro antilithiatic by Titrimetric method, Antioxidant activity by 11-diphenyl -2-picryl hydrazyl scavenging assay method of alcoholic roots and rhizomes extract of Hedychiun coronary J. koenig plant species. Asian Journal of Pharmaceutical and Clinical Research 8(4): 225-229.

2. Arun K Khajuria, NS Bisht (2017) Ethnomedicinal plants used to treat Nephrolithiasis: A case study Pauri (PAURI Garhwal), Uttarakhand. International Journal of Herbal Medicine 5(1): 10-13.

3. Goyal Parveen Kumar, Mittal Arun, Kumar Rishi (2011) Evaluation of Tinosporacordifolia for Anti-urolithiatic Potential. Journal of Pharmaceutical and Biomedical Sciences 9(14).

4. Padama Nibash Pannigrani, Sahadeb Dey, Subash Chandra Jena (2016) Urolithiasis: Critical Analysis of Mechanism of Renal Stone Formation and Use of Medicinal Plants as Anti-urolithiatic Agents. Asian Journal of Animal and Veternary Advances 1(1): 9-16.

5. T Vijaya, M Sathish Kumar, N V Ramarao, A Naredra Babu, N Ramarao (2013) Urolithiasis and Its Causes- Short Review. The Journal of Phytopharmacology 2(3): 1-6.
6. Salman Ahmed, Muhammad Mohtasheemul Hasan, Zafar Alam Mahmood (2016) Anti-urolithiatic plants: Multidimensional pharmacology. Journal of Pharmacognosy and Phytochemistry 5(2): 04-24.

7. Refaz Ahmad Dar, Mohd Shahnawaz, Parvaiz Hassan Qazi (2017) General Overview of Medicinal Plants: A Review. The Journal of Phytopharmacology 6(6): 349-351.

8. Tarek Hamel, Moncef Zaafour, Mahieddine (2018) Knowledge and Traditional Uses of aromatic and Medicinal Plants of the Wetlands Complex of the Guerbes-Sanhadja Plain (Wilaya of Skikda in Northeastern Algeria) 4(1): 3.

9. Yadav RD, Jain SK, Alok S, Amita Verma, A Mahor, et al. (2011) Herbal plants used in the treatment of urolithiasis: a review. International Journal of Pharmaceutical Sciences and Research 2(6): 1412-1420.

10. http://uses.plantnet-project.org>Maeruaagolensis.

11. Nikhilesh Kulkarni, Nikit Kapse, Rachana Pachori, Prithviraj Sadar (2017) Studies on Inhibition of calcium oxalate crystallization by using plant extract and soil microflora. European journal of pharmaceutical and medical research ejpmr 4(8): 329-334.

12. L Sasol, G Valentini, MG Leone, E Grippa, B Silvestrini (1998) Development of an in vitro assay for the screening of substances capable of dissolving calcium oxalate crystals. Urologia Internationalis 61(4): 210-214.

13. Unnati Atodariya, Roshni Barad, Siddhi Upadhyay, Umesh Upadhyay (2013) Anti-Urolithiatic Activity of DolichosBiflorus Seeds. Journal of Pharmacognosy and Phytochemistry 2(2).

14. Sweta Bawari, Archana N Sah, D Tewari (2017) Urolithiasis: An Update on Diagnostic Modalities and Treatment Protocols. Indian J Pharm Sci 79(2): 164-174.

15. Vani Mamillapalli, Padma Latha Khantamneni, Zabeena Mohammad, Anitha Mathangi, Navyanuradha Nandigam, et al. (2016) Phytochemical \& in vitro anti-urolithiatic studies on the leaf extract of Bauhinia variegatalinn. International Journal of Pharmaceutical Sciences and Research (IJPSR) 7(10): 4074-4084.

16. Niharika M, Suchitha N, Akhila S, Himabindhu J, Ramanjaneyulu K (2018) Evaluation of in vitro Anti-urolithiatic Activity of GossypiumHerbaceum. Journal of Pharmacuetical Sciences \& Research 10(5): 1236-1237.

17. Vennila V, Marthal MA (2015) In Vitro Analysis of Phytochemical and Anti-urolithiatic Activity of Various extracts of MeliaDubia leaves. World Journal of Pharmacy and Pharmaceutical Sciences 4(4): 1277-1289. 